Check for updates

Cite this: RSC Adv., 2018, 8, 6231

Received 17th December 2017

Accepted 29th January 2018

DOI: 10.1039/c7ra13397a

rsc.li/rsc-advances

\title{
Synthesis of a series of benzothiazole amide derivatives and their biological evaluation as potent hemostatic agents $\uparrow$
}

\begin{abstract}
Wenqian Nong, (D) a Anran Zhao, ${ }^{\mathrm{b}}$ Jinrui Wei, ${ }^{\mathrm{c}}$ Hui Cheng, ${ }^{\mathrm{a}}$ Xuan Luo ${ }^{\mathrm{a}}$ and Cuiwu Lin ${ }^{\star a}$
A series of benzothiazole amide derivatives were synthesized through a facile and efficient method via a nucleophilic acyl substitution reaction between 2-aminobenzothiazole and various cinnamic acid compounds. The obtained products exhibited good thermal stabilities. All compounds were evaluated for their in vitro hemostatic activities using the commercially available standard drug etamsylate as a positive control. The results showed that compound Q2 had a significant partial coagulation activity, reduced capillary permeability at 5, 10 and $50 \mu \mathrm{mol} \mathrm{L}{ }^{-1}$, activated thrombin activity, and a more potent platelet aggregation activity than the positive control group (etamsylate, up to 1283.9 times in the nanomole range). A molecular modeling study revealed that compound Q2 was a competitive thrombin activator. Therefore, Q2 may be a potential lead for further biological screening and for the generation of drug molecules. Moreover, the structure-activity relationship of the prepared compounds is also discussed herein.
\end{abstract}

\section{Introduction}

Excessive bleeding during surgery remains a main cause of failure of surgical procedures. ${ }^{1}$ Homologous blood transfusion and hemostatic drugs are commonly employed during surgery to avoid excessive bleeding.., ${ }^{2,3}$ However, homologous blood transfusions can increase the risk of infection, leading to increased morbidity and mortality. ${ }^{4}$ Thus, the use of hemostatic agents is preferable. To date, commonly used hemostatic drugs, such as $p$-aminomethylbenzoic acid, tranexamic acid, aminocaproic acid, aprotinin, and etamsylate, confer adverse side effects and safety risks despite their desirable hemostatic effects, and are therefore being re-evaluated for clinical use. ${ }^{4-6}$ Thus, the search for safer and more effective hemostatic agents remains crucial.

A heterocyclic ring containing nitrogen and sulfur atoms represents a unique and universal scaffold for the design of experimental drugs. ${ }^{7}$ Benzothiazole is an important derivative unit of the thiazole ring, a rare heterocyclic compound found in alkaloids, and plays an important role in drug chemistry as

\footnotetext{
${ }^{a}$ Guangxi Colleges and Universities Key Laboratory of Applied Chemistry Technology and Resource Development, School of Chemistry \& Chemical Engineer, Guangxi University, Nanning, 530004, China

${ }^{b}$ Department of Chemistry, Cleveland State University, 2121 Euclid Avenue, Cleveland, OH 44115, USA

${ }^{c}$ Guangxi Scientific Research Center of Traditional Chinese Medicine, Guangxi University of Chinese Medicine, Nanning, Guangxi 530200, PR China

$\dagger$ Electronic supplementary information (ESI) available. CCDC 1582748 and 1582749. For ESI and crystallographic data in CIF or other electronic format see DOI: $10.1039 / \mathrm{c} 7 \mathrm{ra} 13397 \mathrm{a}$
}

a key template for the development of various therapeutic agents. ${ }^{8}$ Due to the presence of sulfur atoms in their structure, benzothiazoles exhibit unique properties not possessed by other heterocyclic compounds. ${ }^{9}$ Benzothiazole amide systems have interesting structural characteristics and strong bioactivity profiles, as well as anticancer, ${ }^{10}$ anti-inflammatory, ${ }^{11}$ antifungal, ${ }^{12}$ and chronic pain suppression properties..$^{13}$ Further, given their useful molecular scaffolds for the exploration and exploitation of pharmacophore space, they have emerged as particularly promising synthetic targets.

Chemical compounds with a low biological toxicity stemming from natural products can be obtained from a wide range of sources, ${ }^{14,15}$ and are being used as lead compounds in the preparation of safe and low toxicity hemostatic drugs. In our previous studies, ${ }^{16,17}$ we evaluated the activity of cinnamic acid amide derivatives synthesized by sulfa drug 2-aminothiazole with cinnamic acid compounds. The results showed that cinnamic acid amide derivatives may function as hemostatic agents. Therefore, we chose to continue our investigation on the synthesis and properties of cinnamic acid compounds.

According to the drug design principles of combination, the covalent bonding of two different compounds would lead to the synergistic effect of their properties. Thus, we designed nine benzothiazole amide derivatives with cinnamic acid structures and assessed their hemostatic activity. Although the synthetic methods of compounds Q5, Q6, Q7, and Q9 have been previously reported, ${ }^{18-20}$ the synthesis of the other compounds Q1Q4, Q8 and the evaluation of their related biological activities remain unreported. Thermogravimetric analysis was used to determine the thermodynamic stability of the compounds as 


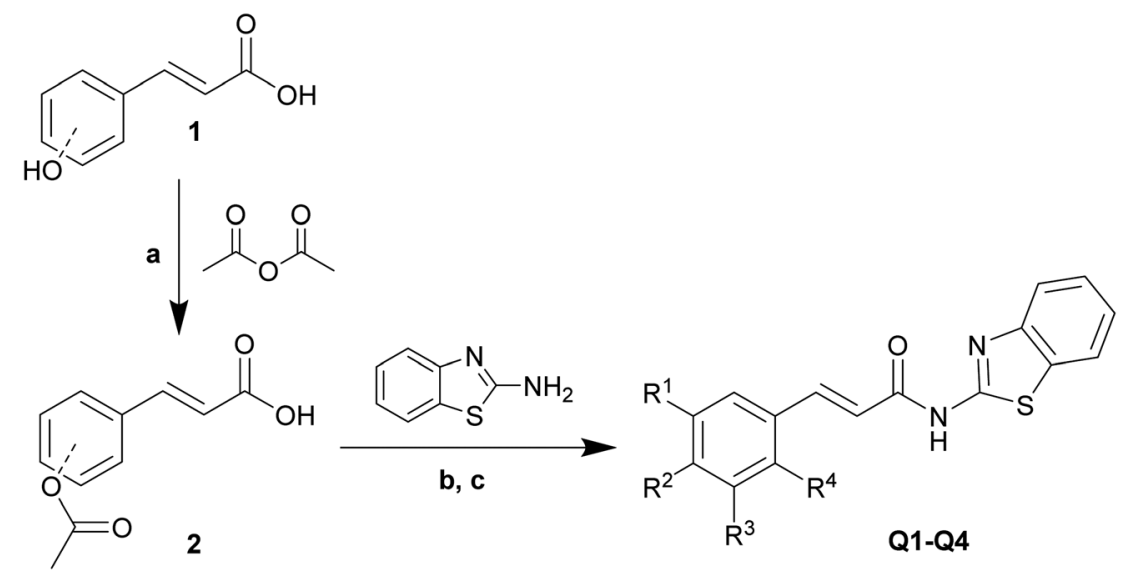

Scheme 1 Synthesis of compounds Q1-Q4. Reagents and conditions: (a) acetic anhydride/pyridine, $120{ }^{\circ} \mathrm{C}, 5 \mathrm{~h}, 98-100 \%$. (b) SOCl , DMF, $70{ }^{\circ} \mathrm{C}, 5 \mathrm{~min}, 100 \%$. (c) $\mathrm{NaHCO}_{3}, \mathrm{pH}=6-7,0-5{ }^{\circ} \mathrm{C}$ to room temperature, $3 \mathrm{~h}, 70-82 \%$.

a proxy of drug stability. The hemostatic activity of the prepared compounds was evaluated by in vitro experiments based on the hemostatic mechanism (involving normal operation of blood vessels, platelets, and blood coagulation) through the platelet aggregation assay, activation of partial thromboplastin time (APTT), prothrombin time (PT), thrombin time assay (TT), human C-type natriuretic peptide determination, and thrombin activity assay (including molecular docking of compound Q2 with thrombin). Based on the obtained results, the relationship between the given structure and the corresponding hemostatic activity was discussed, providing a theoretical basis for the screening of hemostatic drugs.

\section{Results and discussion}

\section{Chemistry}

The amide bond formation reaction is an important reaction in organic synthesis, with the amide bond being widely present in pharmaceutical intermediates and biochemical substances. ${ }^{\mathbf{2 1 , 2 2}}$ Benzothiazole amide derivatives (Q1-Q9) were synthesized by the reaction of cinnamic acid and its derivatives (q1-q9) with 2aminobenzothiazole through the nucleophilic acyl substitution of acyl chloride (Schemes 1 and 2). $\mathrm{NaHCO}_{3}$ was used as an acid binding agent and the reaction was performed in $\mathrm{CH}_{2} \mathrm{Cl}_{2}$ solvent at $0-5{ }^{\circ} \mathrm{C}$. The $\mathrm{pH}$ value was kept between 6 and 7 by addition of $\mathrm{NaHCO}_{3}$ to induce precipitation. The reactants were vigorously mixed until solidification of the reaction mixture.
Reaction progress was monitored by thin layer chromatography (TLC). Once the reaction was complete, the upper layer solid was collected by filtration of the mixture. The solid product was washed with excess distilled ethanol and water to obtain the pure products. All tested reactions proceeded smoothly under optimal conditions, producing the desired products in good yields (Table 1). However, a trend was observed wherein using cinnamic acid derivatives with substituents of increasing electron-donating strength on the aromatic ring led to products with higher yields, likely due to a decrease in electron density in the aromatic ring causing an acceleration of the reaction. Compounds Q1-Q9 were structurally characterized by various spectroscopic techniques, including ${ }^{1} \mathrm{H}$ and ${ }^{13} \mathrm{C}$ nuclear magnetic resonance (NMR), electron ionization mass spectroscopy, and Fourier-transform infrared spectroscopy.

\section{Crystal structure description}

Single crystals of compounds Q7 (CCDC: 1582748) and Q9 (CCDC: 1582749) were grown from dimethyl sulfoxide and the corresponding structures were confirmed by single crystal X-ray diffraction analysis (Fig. 1). Furthermore, integrals in the NMR spectra confirmed the crystal structures for the two compounds Q7 and Q9. The crystal lattice of compound Q7 belongs to the triclinic system. The crystal lattice of compound Q9 belongs to the monoclinic system, containing two $N$-(benzo[d]thiazol-2-yl)3-phenylpropanamide molecules. Selected bond lengths $(\AA)$ and angles $\left({ }^{\circ}\right)$ are provided in the ESI $\dagger$ section.<smiles>[R]c1cc(/C=C/C(=O)O)c([R])c([R])c1[R]</smiles>

Scheme 2 Synthesis of compounds Q5-Q9. Reagents and conditions: (b) $\mathrm{SOCl}_{2}, \mathrm{DMF}, 70{ }^{\circ} \mathrm{C}, 5 \mathrm{~min}, 100 \%$. (c) $\mathrm{NaHCO}, \mathrm{pH}=6-7,0-5{ }^{\circ} \mathrm{C}$ to room temperature, 3 h, $88-93 \%$. 
Table 1 Synthesis of benzothiazole amide derivatives ${ }^{a}$ and their biological evaluation on platelet aggregation<smiles>[R]c1cc(/C=C/C(=O)O)c([R])c([R])c1[14CH3]</smiles><smiles>O=C(O)CCc1ccccc1</smiles><smiles>[R]c1cc(/C=C/C(=O)Nc2nc3ccccc3s2)c([R])c([R])c1[R]</smiles><smiles>O=C(CCc1ccccc1)Nc1nc2ccccc2s1</smiles>

\begin{tabular}{|c|c|c|c|c|c|c|}
\hline Compound & $R^{1}$ & $R^{2}$ & $R^{3}$ & $R^{4}$ & Yield $^{b}(\%)$ & $\mathrm{EC}_{50}^{c}\left(\mu \mathrm{mol} \mathrm{L}{ }^{-1}\right)$ \\
\hline 2-Aminobenzothiazole & & & & & & 513.7 \\
\hline $\mathbf{q} 1^{d}$ & $\mathrm{H}$ & $\mathrm{OCOCH}_{3}$ & $\mathrm{OCH}_{3}$ & $\mathrm{H}$ & 100 & 476.3 \\
\hline $\mathbf{q} 3^{d}$ & $\mathrm{H}$ & $\mathrm{H}$ & $\mathrm{OCOCH}_{3}$ & $\mathrm{H}$ & 98 & 129.4 \\
\hline $\mathbf{q} 4^{d}$ & $\mathrm{H}$ & $\mathrm{H}$ & $\mathrm{H}$ & $\mathrm{OCOCH}_{3}$ & 98 & 108.7 \\
\hline $\mathbf{q} 5^{e}$ & $\mathrm{H}$ & $\mathrm{H}$ & $\mathrm{H}$ & $\mathrm{H}$ & & 322.3 \\
\hline $\mathbf{q} 8^{e}$ & $\mathrm{OCH}_{3}$ & $\mathrm{OCH}_{3}$ & $\mathrm{OCH}_{3}$ & $\mathrm{H}$ & & 120.9 \\
\hline $\mathbf{q} 9^{e}$ & - & - & - & - & & 227.8 \\
\hline Q1 & $\mathrm{H}$ & $\mathrm{OCOCH}_{3}$ & $\mathrm{OCH}_{3}$ & $\mathrm{H}$ & 82 & 93.87 \\
\hline Q2 & $\mathrm{H}$ & $\mathrm{OCOCH}_{3}$ & $\mathrm{H}$ & $\mathrm{H}$ & 73 & 0.036 \\
\hline Q3 & $\mathrm{H}$ & $\mathrm{H}$ & $\mathrm{OCOCH}_{3}$ & $\mathrm{H}$ & 77 & 1.246 \\
\hline Q4 & $\mathrm{H}$ & $\mathrm{H}$ & $\mathrm{H}$ & $\mathrm{OCOCH}_{3}$ & 70 & 0.119 \\
\hline Q9 & - & - & - & - & 90 & 35.47 \\
\hline Etamsylate & & & & & & 46.22 \\
\hline
\end{tabular}

${ }^{a}$ Reaction conditions: the acid chloride of cinnamic acid compounds $(1.5 \mathrm{mmol}), 2$-aminobenzothiazole $(1.0 \mathrm{mmol})$ in $10.0 \mathrm{~mL} \mathrm{of} \mathrm{CH}_{2} \mathrm{Cl}_{2}, 0-5{ }^{\circ} \mathrm{C}$ to room temperature, $3 \mathrm{~h} .{ }^{b}$ Isolated yield after flash chromatography. ${ }^{c}$ The $\mathrm{EC}_{50}$ values are expressed as the concentration required to promote ADPinduced human platelet aggregation response by $50 \% ; n=3{ }^{d}$ Reaction conditions: cinnamic acid compounds (ferulic acid, $p$-hydroxy-cinnamic acid, $m$-hydroxycinnamic acid, and $o$-hydroxy-cinnamic acid, $25.0 \mathrm{~g})$, pyridine $(5 \mathrm{~mL})$ in $100 \mathrm{~mL}$ of acetic anhydride at $120{ }^{\circ} \mathrm{C}$ for $5 \mathrm{~h} .{ }^{e} \mathbf{q} 5$ : cinnamic acid; q6: 4-methoxycinnamic acid; q7: 3,4-dimethoxycinnamic acid; q8: 3,4,5-trimethoxycinnamic acid; q9: 3-phenylpropionic acid.

\section{Thermogravimetric analysis}

The mass loss and heat flow of the benzothiazole amide derivatives upon increasing temperature are shown in Fig. 2. When the compounds were heated to below $100{ }^{\circ} \mathrm{C}$, no significant changes in mass were observed. With the increase in temperature, the mass loss gradually increased, with the heat flow curve showing obvious fluctuations at approximately $150{ }^{\circ} \mathrm{C}$, indicating the initiation of oxidation in air. The mass of $\mathbf{Q} 4$ declined considerably at $180{ }^{\circ} \mathrm{C}$, with the heat flow curve showing a large fluctuation due to sample decomposition.

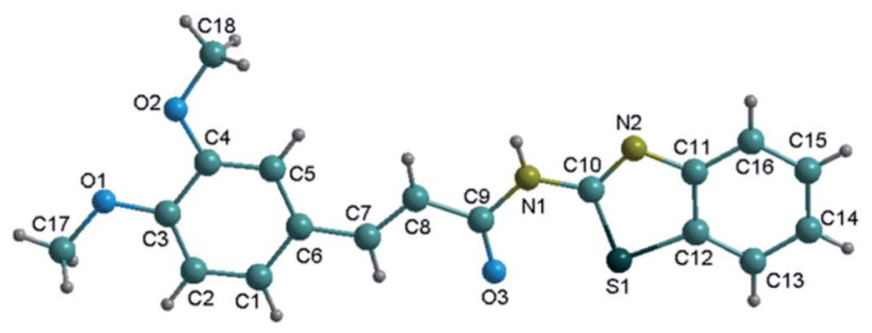

Q7
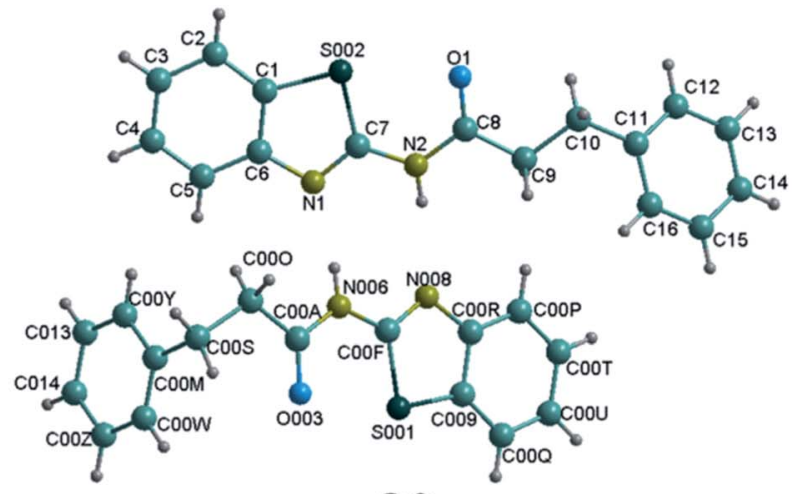

Q9

Fig. 1 Ball-and-stick structures of compounds Q7 and Q9. 


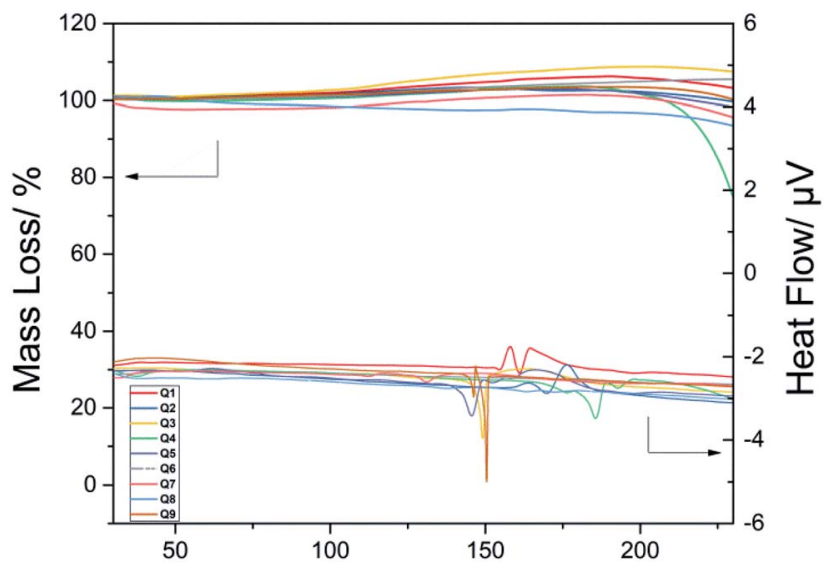

Fig. 2 Thermogravimetric and heat flow curves of compounds Q1Q9 recorded at a constant heating rate. The mass loss is expressed as the fraction $M / M_{0}$ of the mass at temperature $T$ to the initial mass of the samples equilibrated at laboratory atmosphere.

Thus, the stable nature of the thermogravimetric analysis results indicated that the prepared compounds had a suitable thermal stability at $100{ }^{\circ} \mathrm{C}$. Therefore, these compounds were further screened as hemostatic drugs.

\section{Platelet aggregation activity}

When the vascular wall is broken, platelets undergo a series of functional responses, including adhesion, diffusion, release, and accumulation, thus promoting coagulant surface exposure, particle formation, and clot retraction. ${ }^{23}$ The platelet accumulation response leads to platelet adhesion at the site of injury as well as the action of endogenous agonists such as adenosine diphosphate (ADP), collagen, and thrombin, followed by the release of $\mathrm{TXA}_{2}$, forming a hemostatic plug to obstruct the severed area and prevent bleeding. ${ }^{24,25}$ Compound Q2 showed the highest efficacy as a platelet aggregation promoter, with the lowest $\mathrm{EC}_{50}$ value $\left(0.036 \mu \mathrm{mol} \mathrm{L}^{-1}\right)$ in the nanomole range $\left(10 \mathrm{nmol} \mathrm{L}^{-1}\right)$, demonstrating a better platelet aggregation activity than etamsylate (positive control, $\mathrm{EC}_{50}=$ 46.22 $\mu \mathrm{mol} \mathrm{L}^{-1}$; Table 1). Compounds Q4, Q3, Q8, Q7, and Q9 $\left(\mathrm{EC}_{50}=0.119,1.246,1.867,18.09\right.$, and $\left.35.47 \mu \mathrm{mol} \mathrm{L}^{-1}\right)$ all showed a better platelet aggregation-promoting activity than etamsylate. Thus, adding methoxy groups to $N$-(benzo $[d]$ thiazol-2-yl)-cinnamamide leads to a decrease in platelet aggregation activity. However, introducing an acetoxyl group to $N$-(benzo $[d]$ thiazol-2-yl) cinnamamide would lead to an increase in platelet aggregation activity. Thus, the substituent type crucially affects platelet aggregation promotion.

\section{Blood coagulation activities}

All synthetic benzothiazole amide derivatives Q1-Q9 were screened for in vitro blood coagulant activity, including APTT, PT, and TT assays. APTT tests the intrinsic coagulation activity, providing an approximate indication of coagulation factor II, V, VII, and X activity. ${ }^{26} \mathrm{PT}$ is an ideal and commonly used screening assay for the detection of extrinsic coagulation pathway. ${ }^{27}$ Finally, TT is a screening test to determine thrombin activity and the ability to convert plasma fibrin into fibrin. ${ }^{28}$ The coagulation rate $\left(R_{\mathrm{xx}}\right)$ was used to evaluate the corresponding coagulation activity of a given compound; negative values may represent partial coagulation activity and smaller values may indicate an improvement in the blood coagulant effects. The corresponding

Table $2 R_{\text {APT }}$ (\%) values of the synthesized benzothiazole amide derivatives ${ }^{a}$

$\underline{\text { Concentration }\left(\mu \mathrm{mol} \mathrm{L}^{-1}\right)}$

\begin{tabular}{|c|c|c|c|c|c|}
\hline Compound & 1 & 5 & 10 & 50 & 100 \\
\hline Etamsylate & $-7.12 \pm 0.23$ & $-6.10 \pm 0.22$ & $-4.52 \pm 0.46$ & $-1.01 \pm 0.25$ & $4.07 \pm 0.12$ \\
\hline 2-Aminobenzothiazole & $-4.87 \pm 0.13 * * *$ & $-5.27 \pm 0.35$ & $-6.19 \pm 0.13^{* * *}$ & $-4.74 \pm 0.23 * * *$ & $-4.48 \pm 0.35^{* * *}$ \\
\hline q1 & $-1.72 \pm 0.25^{* * *}$ & $-0.54 \pm 0.16^{* * *}$ & $0.86 \pm 0.25^{* * *}$ & $1.58 \pm 0.14^{* * *}$ & $1.87 \pm 0.38^{* * *}$ \\
\hline q2 & $-3.97 \pm 0.47^{* * *}$ & $-3.56 \pm 0.24^{* * *}$ & $-1.92 \pm 0^{* * *}$ & $0.01 \pm 0.27$ & $0.82 \pm 0.14^{* * *}$ \\
\hline q3 & $-2.19 \pm 0.36^{* * *}$ & $-1.23 \pm 0.27^{* * *}$ & $0.55 \pm 0.24^{* * *}$ & $0.96 \pm 0.24^{* * *}$ & $3.15 \pm 0.14$ \\
\hline q4 & $-3.47 \pm 0.12^{* * *}$ & $-1.20 \pm 0.24^{* * *}$ & $-0.96 \pm 0.32^{* * *}$ & $0.12 \pm 0.24^{*}$ & $0.24 \pm 0.43^{* * *}$ \\
\hline q5 & $-2.18 \pm 0.39 * * *$ & $-0.26 \pm 0.38^{* * *}$ & $2.05 \pm 0.44^{* * *}$ & $2.56 \pm 0.26^{* * *}$ & $7.57 \pm 0.34^{* * *}$ \\
\hline q6 & $-0.96 \pm 0.32 * * *$ & $0.12 \pm 0.11^{* * *}$ & $0.36 \pm 0.35 * * *$ & $0.60 \pm 0.32^{* *}$ & $0.72 \pm 0.21^{* * *}$ \\
\hline q7 & $-0.73 \pm 0.15^{* * *}$ & $-0.44 \pm 0.44^{* * *}$ & $1.91 \pm 0.14^{* * *}$ & $2.20 \pm 0.25^{* * *}$ & $2.79 \pm 0.15^{*}$ \\
\hline q8 & $-0.48 \pm 0.24 * * *$ & $-0.84 \pm 0.60^{* * *}$ & $-1.20 \pm 0.43 * * *$ & $-1.67 \pm 0.12$ & $-2.75 \pm 0.24^{* * *}$ \\
\hline q9 & $1.03 \pm 0.12^{* * *}$ & $-0.77 \pm 0.26^{* * *}$ & $-1.67 \pm 0.13 * * *$ & $-2.31 \pm 0.33^{*}$ & $-2.57 \pm 0.22 * * *$ \\
\hline Q1 & $0.14 \pm 0.37^{* * *}$ & $-8.58 \pm 0.37^{* * *}$ & $-10.10 \pm 0.14^{* * *}$ & $-6.50 \pm 0.14^{* * *}$ & $-5.26 \pm 0.37^{* * *}$ \\
\hline Q2 & $-38.84 \pm 0.08^{* * *}$ & $-38.26 \pm 0 * * *$ & $-36.12 \pm 0.22 * * *$ & $-36.03 \pm 0.43 * * *$ & $-20.25 \pm 0.30 * * *$ \\
\hline Q3 & $0.42 \pm 0.38^{* * *}$ & $0.21 \pm 0.21 * * *$ & $-1.98 \pm 0.21^{* * *}$ & $-0.73 \pm 0.21$ & $-0.52 \pm 0.10^{* * *}$ \\
\hline Q4 & $-35.46 \pm 0.17^{* * *}$ & $-34.96 \pm 0.30 * * *$ & $-34.22 \pm 0.22^{* * *}$ & $-31.90 \pm 0.41^{* * *}$ & $-4.80 \pm 0.14^{* * *}$ \\
\hline Q5 & $-12.06 \pm 0.20^{* * *}$ & $-10.03 \pm 0.34^{* * *}$ & $-9.58 \pm 0.11^{* * *}$ & $-9.47 \pm 0.29 * * *$ & $-7.89 \pm 0.11^{* * *}$ \\
\hline Q6 & $-9.47 \pm 0.11^{* * *}$ & $-8.90 \pm 0.11^{* * *}$ & $-8.46 \pm 0.41^{* * *}$ & $-7.90 \pm 0.11^{* * *}$ & $-7.33 \pm 0.34^{* * *}$ \\
\hline Q7 & $-4.55 \pm 0.28^{* * *}$ & $-6.21 \pm 0.14$ & $-8.83 \pm 0.14^{* * *}$ & $-7.31 \pm 0.24^{* * *}$ & $-4.41 \pm 0.24^{* * *}$ \\
\hline Q8 & $2.24 \pm 0.11^{* * *}$ & $-0.11 \pm 0.11^{* * *}$ & $-4.69 \pm 0.18$ & $-3.52 \pm 0.11^{* * *}$ & $0.85 \pm 0.11^{* * *}$ \\
\hline Q9 & $-5.75 \pm 0.30 * * *$ & $-4.06 \pm 0.46^{* * *}$ & $-3.95 \pm 0.20$ & $-1.01 \pm 0.30$ & $4.51 \pm 0.20$ \\
\hline
\end{tabular}

${ }^{a}$ Data represent mean \pm SEM; $n=8 .{ }^{*} P<0.05$ vs. etamsylate; ${ }^{* *} P<0.01$ vs. etamsylate; ${ }^{* * *} P<0.001$ vs. etamsylate. 
Table $3 R_{\mathrm{PT}}(\%)$ values of the synthesized benzothiazole amide derivatives ${ }^{a}$

\begin{tabular}{|c|c|c|c|c|c|}
\hline \multirow[b]{2}{*}{ Compound } & \multicolumn{5}{|c|}{ Concentration $\left(\mu \mathrm{mol} \mathrm{L}^{-1}\right)$} \\
\hline & 1 & 5 & 10 & 50 & 100 \\
\hline 2-Aminobenzothiazole & $-1.05 \pm 0.46^{* * *}$ & $-1.22 \pm 0.30^{* * *}$ & $-1.57 \pm 0.17^{* * *}$ & $-4.36 \pm 0^{* * *}$ & $-4.48 \pm 0.35^{* * *}$ \\
\hline q1 & $7.60 \pm 0.17^{* * *}$ & $4.73 \pm 0.45^{* * *}$ & $2.87 \pm 0.59 * *$ & $-1.35 \pm 0.45^{* * *}$ & $-2.20 \pm 0.29 * * *$ \\
\hline q2 & $-4.78 \pm 0.27^{* * *}$ & $-3.85 \pm 0.27^{* * *}$ & $-3.70 \pm 0.15^{* * *}$ & $-3.39 \pm 0.27^{* * *}$ & $-2.93 \pm 0.27^{* * *}$ \\
\hline q5 & $-5.94 \pm 0.45^{* * *}$ & $-2.53 \pm 0.39 * * *$ & $-1.78 \pm 0.15^{* * *}$ & $-0.45 \pm 0.39^{* * *}$ & $2.23 \pm 0.54^{* *}$ \\
\hline q6 & $-4.16 \pm 0.15^{* * *}$ & $-3.23 \pm 0.56^{* * *}$ & $-2.31 \pm 0.41 * * *$ & $-1.23 \pm 0.15^{* * *}$ & $-0.15 \pm 0.27^{* * *}$ \\
\hline q7 & $-0.77 \pm 0.41^{* * *}$ & $0.77 \pm 0.27^{* * *}$ & $1.23 \pm 0.27^{* * *}$ & $1.69 \pm 0.46$ & $1.85 \pm 0.31^{* *}$ \\
\hline q8 & $1.52 \pm 0.45^{* * *}$ & $3.21 \pm 0.34^{* * * *}$ & $4.39 \pm 0.29^{* * *}$ & $5.57 \pm 0.45^{* * *}$ & $6.76 \pm 0.34^{* * *}$ \\
\hline q9 & $-5.42 \pm 0.54^{* * *}$ & $-1.51 \pm 0.26^{* * *}$ & $-1.05 \pm 0.45^{* * *}$ & $-0.45 \pm 0.40^{* * *}$ & $1.51 \pm 0.15^{* * *}$ \\
\hline Q1 & $-2.12 \pm 0.28 * * *$ & $-5.22 \pm 0.33^{* * *}$ & $-4.73 \pm 0.16^{* * *}$ & $-3.59 \pm 0.57^{* * *}$ & $-2.12 \pm 0.28^{* * *}$ \\
\hline Q6 & $-4.57 \pm 0.48^{* * *}$ & $-4.70 \pm 0.13^{* * *}$ & $-6.99 \pm 0.13 * * *$ & $-9.54 \pm 0.13^{* * *}$ & $-14.79 \pm 0.13^{* * *}$ \\
\hline Q7 & $-3.57 \pm 0.28 * * *$ & $-4.40 \pm 0.16^{* * *}$ & $-5.38 \pm 0.33^{* * *}$ & $-6.85 \pm 0.16^{* * *}$ & $-7.83 \pm 0.33^{* * *}$ \\
\hline Q8 & $-1.61 \pm 0.13 * * *$ & $-4.29 \pm 0 * * *$ & $-3.89 \pm 0.23 * * *$ & $-4.83 \pm 0.27^{* * *}$ & $-1.21 \pm 0.13^{* * *}$ \\
\hline Q9 & $-9.82 \pm 0.27 * * *$ & $-6.72 \pm 0.13 * * *$ & $-5.19 \pm 0.13 * * *$ & $-4.03 \pm 0.23^{* * *}$ & $-3.90 \pm 0.27^{* * *}$ \\
\hline
\end{tabular}

${ }^{a}$ Data represent mean \pm SEM; $n=8 .{ }^{*} P<0.05$ vs. etamsylate; ${ }^{* *} P<0.01$ vs. etamsylate; ${ }^{* * *} P<0.001$ vs. etamsylate.

APTT, PT, and TT values of benzothiazole amide derivatives and etamsylate (positive control) are shown in Tables $2-4$, while a comparison with $p$-aminomethylbenzoic acid (another positive control) are provided in the $\mathrm{ESI} \dagger$ section.

Compound Q2 exhibited the lowest APTT value $\left(R_{\mathrm{APTT}}=\right.$ $-38.84 \pm 0.08 \%$ at $1 \mu \mathrm{mol} \mathrm{L}{ }^{-1}$; Table 2$)$, a significantly shortened TT $\left(P<0.001\right.$, except $1 \mu \mathrm{mol} \mathrm{L}{ }^{-1}$; Table 4$)$, and a somewhat shortened PT compared to the positive control etamsylate. The blood coagulant mechanism is most likely due to compound Q2 primarily coagulating blood through the activation of intrinsic pathways and partly through thrombin-mediated promotion of fibrinogen conversion to fibrin in plasma.

Compound Q6 exhibited the lowest PT value $\left(R_{\mathrm{PT}}=-14.79 \pm\right.$ $0.13 \%$ at $100 \mu \mathrm{mol} \mathrm{L}^{-1}$; Table 3 ), with its activity decreasing with

Table $4 R_{\pi}$ (\%) values of the synthesized benzothiazole amide derivatives ${ }^{a}$

Concentration $\left(\mu \mathrm{mol} \mathrm{L}{ }^{-1}\right)$

\begin{tabular}{|c|c|c|c|c|c|}
\hline Compound & 1 & 5 & 10 & 50 & 100 \\
\hline Etamsylate & $-11.75 \pm 0.34$ & $-1.92 \pm 0.24$ & $5.51 \pm 0.44$ & $11.51 \pm 0.33$ & $16.04 \pm 0.17$ \\
\hline 2-Aminobenzothiazole & $12.57 \pm 0.29 * * *$ & $11.40 \pm 0 * * *$ & $9.36 \pm 0.29 * * *$ & $3.51 \pm 0.31^{* * *}$ & $0.58 \pm 0.29 * * *$ \\
\hline q1 & $0.26 \pm 0.26^{* * *}$ & $-0.52 \pm 0.26^{*}$ & $-1.82 \pm 0.26^{* * *}$ & $-3.16 \pm 0.45^{* * *}$ & $-5.47 \pm 0.45^{* * *}$ \\
\hline q2 & $-2.53 \pm 0.51 * * *$ & $-1.52 \pm 0.25$ & $1.01 \pm 0.44^{* * *}$ & $2.03 \pm 0.25 * * *$ & $4.30 \pm 0.51 * * *$ \\
\hline q3 & $0.98 \pm 0.42 * * *$ & $-0.98 \pm 0.24$ & $-4.39 \pm 0.24 * * *$ & $-5.61 \pm 0.42^{* * *}$ & $-6.10 \pm 0.24^{* * *}$ \\
\hline q4 & $-4.95 \pm 0.26^{* * *}$ & $-3.91 \pm 0 * *$ & $-2.87 \pm 0.26^{* * *}$ & $-1.82 \pm 0.52^{* * *}$ & $-1.56 \pm 0.45^{* * *}$ \\
\hline q5 & $-6.58 \pm 0.44^{* * *}$ & $-5.32 \pm 0.25 * * *$ & $-0.76 \pm 0.51 * * *$ & $1.77 \pm 0.44^{* * *}$ & $3.54 \pm 0.25 * * *$ \\
\hline q6 & $-2.29 \pm 0.43^{* * *}$ & $-1.02 \pm 0.51$ & $-0.51 \pm 0.25^{* * *}$ & $0.51 \pm 0.67^{* * *}$ & $2.04 \pm 0.25^{* * *}$ \\
\hline q7 & $-4.15 \pm 0^{* * *}$ & $-1.71 \pm 0.24$ & $2.44 \pm 0.42^{* * *}$ & $5.12 \pm 0.49^{* * *}$ & $8.29 \pm 0 * * *$ \\
\hline q8 & $-4.30 \pm 0.44^{* *}$ & $-2.28 \pm 0.25$ & $-1.27 \pm 0.44 * * *$ & $2.03 \pm 0.51^{* * *}$ & $3.04 \pm 0.25^{* * *}$ \\
\hline q9 & $-4.12 \pm 0.45^{* * *}$ & $-2.06 \pm 0.26$ & $-1.55 \pm 0.26 * * *$ & $0.01 \pm 0.52^{* * *}$ & $1.03 \pm 0.25 * * *$ \\
\hline Q1 & $-7.38 \pm 0.22 * * *$ & $-11.50 \pm 0.38 * * *$ & $-12.15 \pm 0.38 * * *$ & $-12.80 \pm 0.01 * * *$ & $-14.53 \pm 0.22^{* * *}$ \\
\hline Q2 & $-6.67 \pm 0.24^{* * *}$ & $-11.43 \pm 0.41^{* * *}$ & $-17.14 \pm 0.01 * * *$ & $-24.52 \pm 0.24 * * *$ & $-16.43 \pm 0.41^{* * *}$ \\
\hline Q3 & $-3.11 \pm 0.19 * * *$ & $-4.47 \pm 0 * * *$ & $-16.70 \pm 0.34^{* * *}$ & $-14.18 \pm 0.19^{* * *}$ & $-9.13 \pm 0.34 * * *$ \\
\hline Q4 & $-21.91 \pm 0.28^{* * *}$ & $-20.24 \pm 0.24 * * *$ & $-18.10 \pm 0.24 * * *$ & $-15.00 \pm 0.41 * * *$ & $-13.33 \pm 0.24^{* * *}$ \\
\hline Q5 & $-10.56 \pm 0.10^{*}$ & $-11.97 \pm 0.41 * * *$ & $-13.62 \pm 0.23 * * *$ & $-20.19 \pm 0.23 * * *$ & $-20.66 \pm 0.47^{* * *}$ \\
\hline Q6 & $-14.46 \pm 0.24 * * *$ & $-10.9 \pm 0.24 * * *$ & $-5.21 \pm 0.47 * * *$ & $-4.98 \pm 0.47 * * *$ & $-0.95 \pm 0.24^{* * *}$ \\
\hline Q7 & $-19.31 \pm 0.38^{* * *}$ & $-17.57 \pm 0.22^{* * *}$ & $-17.14 \pm 0.22^{* * *}$ & $-16.05 \pm 0.38 * * *$ & $-13.23 \pm 0.22 * * *$ \\
\hline Q8 & $-29.13 \pm 0.39 * * *$ & $-28.35 \pm 0.01 * * *$ & $-27.96 \pm 0.19 * * *$ & $-16.31 \pm 0.39 * * *$ & $-13.20 \pm 0.34 * * *$ \\
\hline Q9 & $-2.61 \pm 0.41 * * *$ & $-3.79 \pm 0.24 * * *$ & $-11.61 \pm 0.24 * * *$ & $-17.54 \pm 0.41^{* * *}$ & $-18.48 \pm 0.24 * * *$ \\
\hline
\end{tabular}

${ }^{a}$ Data represent mean $\pm \mathrm{SEM} ; n=8 .{ }^{*} P<0.05$ vs. etamsylate; ${ }^{* *} P<0.01$ vs. etamsylate; ${ }^{* * *} P<0.001$ vs. etamsylate. 


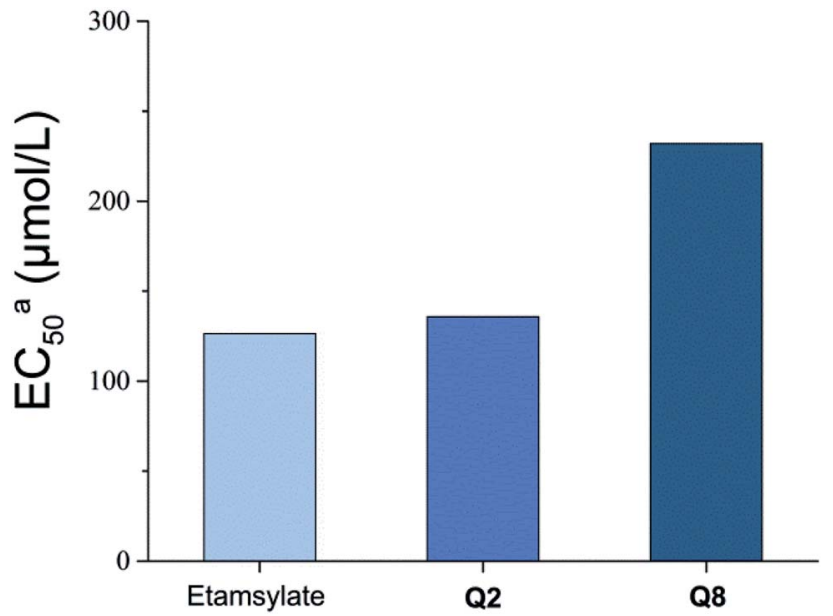

Fig. 3 The $\mathrm{EC}_{50}$ values for the activation of thrombin activity by compounds Q2 and Q8. ${ }^{\text {TT The }} \mathrm{EC}_{50}$ values are expressed as the concentration required for a thrombin activity response of $50 \% ; n=3$.

decreasing concentration. Nevertheless, Q6 showed a lower activity than etamsylate at 1,5 and $10 \mu \mathrm{mol} \mathrm{L}{ }^{-1}$, and a higher activity at 50 and $100 \mu \mathrm{mol} \mathrm{L}^{-1}$. Further, it showed the lowest $R_{\mathrm{PT}}$ value at $1 \mu \mathrm{mol} \mathrm{L}{ }^{-1}(-13.70 \pm 0.37 \%)$. The PT values of other compounds were higher than $-10 \%$, indicating that the extrinsic pathways were less affected.

Compound Q8 exhibited the lowest TT value $\left(R_{\mathrm{TT}}=-29.13 \pm\right.$ $0.39 \%$; Table 4). However, a rare effect on APTT and PT was observed, wherein the $R_{\mathrm{APTT}}$ and $R_{\mathrm{PT}}$ values of $\mathbf{Q 8}$ were all lower than $-5 \%$ (which can be regarded as no activity), indicating that

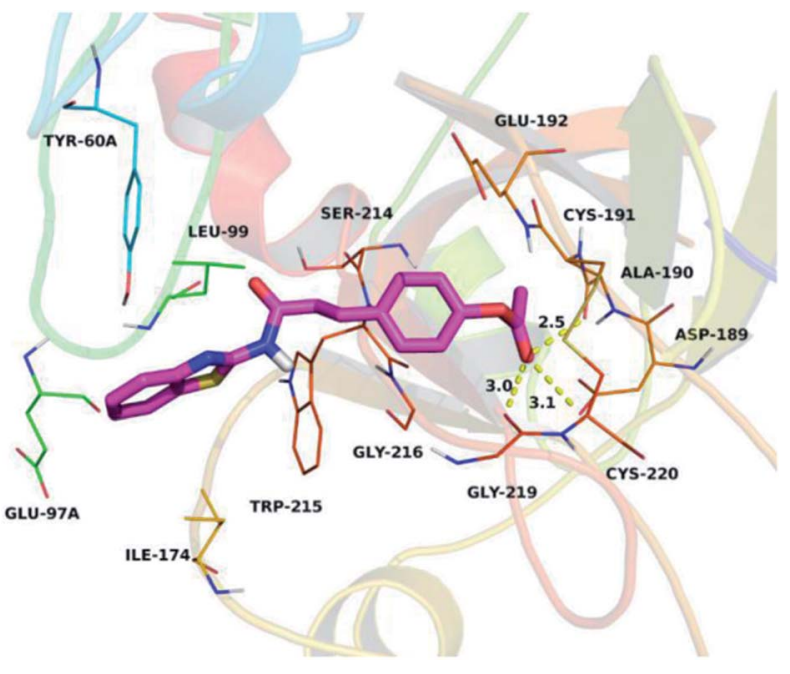

Fig. 5 Compound Q2 docking into the thrombin binding pocket.

compound Q8 mainly achieved a blood coagulation effect through stimulation of fibrinogen or an increase of fibrin levels. However, coagulation was not observed to be due to intrinsic or extrinsic pathways.

Combined with blood coagulant activity, $N$-(benzo[ $d]$ thiazol2-yl)-cinnamamide with a methoxy group substitution lead to a decrease in APTT and PT. Conversely, introducing an acetoxyl group to $N$-(benzo[d]thiazol-2-yl) cinnamamide lead to an increase in APTT, but a decrease in PT. Moreover, the position of the acetoxyl group was also observed to influence the relevant hemostatic activity, where APTT and PT were increased when

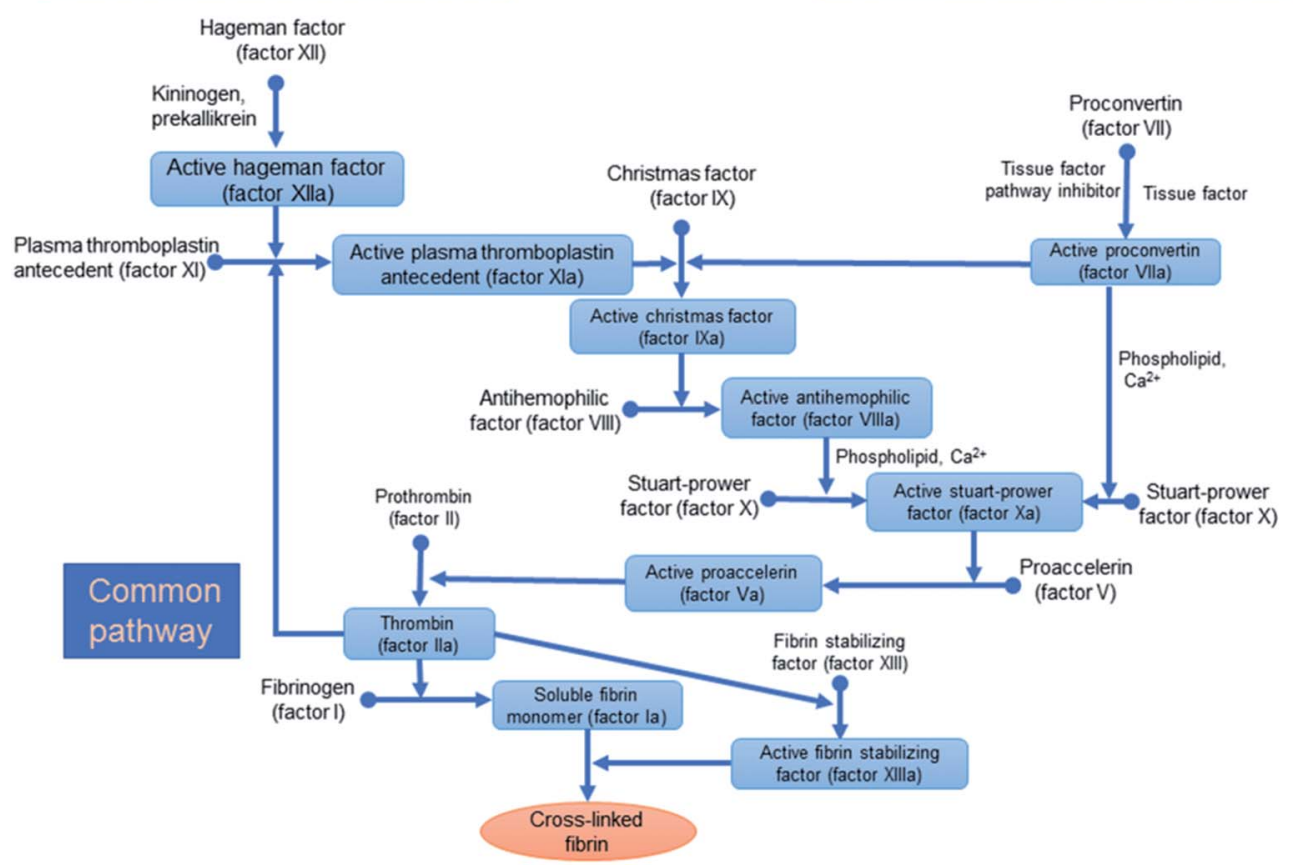

Fig. 4 The classical systems for blood coagulation including extrinsic, intrinsic, and/or the common coagulation pathways. ${ }^{30}$ 


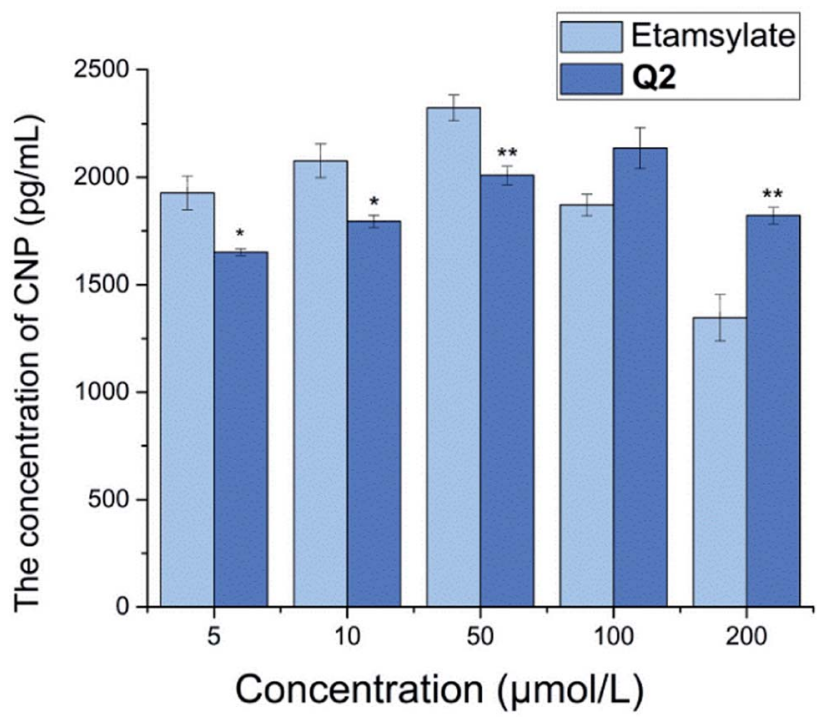

Fig. 6 Effects of compounds Q2 and etamsylate on capillary permeability. The results were expressed as the concentration of CNP $\left(\mathrm{pg} \mathrm{mL}^{-1}\right)$. Values are reported as the mean \pm SEM of three independent experiments.

the acetoxyl group was located in the ortho or para positions in the benzene ring compared to the meta position.

\section{Thrombin activity assay}

Thrombin is a key component in blood coagulation, positioned in the coagulation cascade to cleave fibrinogen into fibrin, resulting in blood clot formation. ${ }^{29} \mathbf{Q 2}$ and $\mathbf{Q 8}$, which had a good coagulation activity, were selected for thrombin activity assays (Fig. 3). The $\mathrm{EC}_{50}$ of thrombin activity of Q2 $(135.9 \mu \mathrm{mol}$ $\left.\mathrm{L}^{-1}\right)$ and $\mathbf{Q 8}\left(232.1 \mu \mathrm{mol} \mathrm{L}{ }^{-1}\right)$ were both lower than for etamsylate $\left(126.5 \mu \mathrm{mol} \mathrm{L}{ }^{-1}\right)$. In combination with blood coagulant activity results and the fact that Q2 significantly shortened APTT and TT compared to etamsylate, we can infer that the coagulation activity mechanism of $\mathbf{Q} 2$ functioned through its interaction with thrombin as well as with other proteins or factors in the blood coagulation cascade (Fig. 4).

\section{Docking of compound Q2 with thrombin}

To further assess the interaction mode of compound Q2 with thrombin, a molecular docking study was performed using Autodock vina 1.1.2 software. ${ }^{31}$ The theoretical binding mode of Q2 in the thrombin binding site is illustrated in Fig. 5. Q2 adopted a compact conformation to bind inside the thrombin pocket. The benzothiazolyl group of $\mathbf{Q} 2$ was located within the hydrophobic pocket, surrounded by Tyr-60A, Leu-99, Ile-174, and Trp-215 residues, forming stable hydrophobic bonding. Detailed analysis showed that the phenyl group of Q2 formed anion- $\pi$ interactions with Asp-189 and Glu-192 residues. Importantly, three key polar interactions were observed between the carbonyl "O" of Q2 and Asp-189 (bond distance: 3.1 $\AA$ ), Ala-190 (bond distance: $2.5 \AA$ ), and Gly-219 (bond distance: 3.0 $\mathrm{A}$ ), representing the main interactions between thrombin and Q2 and facilitating Q2 anchoring within the thrombin binding site. The above molecular simulations elucidated the underlying interactions between Q2 and thrombin, providing valuable information for the further development of thrombin activators.

\section{In vitro determination of human C-type natriuretic peptide (CNP)}

$\mathrm{CNP}$, a local vascular regulator, is a member of the natriuretic family, ${ }^{32}$ with potent vasodilator properties. ${ }^{33}$ The level of CNP in plasma and tissue has been shown to increase upon vascular injury, with a decrease in CNP content suggesting that vascular injury has improved..$^{34}$ At low concentrations $(5,10$, and $50 \mu \mathrm{mol}$ $\mathrm{L}^{-1}$ ), the plasma CNP level of $\mathbf{Q} 2$ was significantly lower than that of etamsylate $(P<0.05$ or $P<0.01$; Fig. 6). Yet, at high concentrations (100 and $200 \mu \mathrm{mol} \mathrm{L} \mathrm{L}^{-1}$ ), the reverse was observed. Etamsylate is able to reduce capillary permeability. ${ }^{35-38}$ Thus, we could infer that $\mathbf{Q 2}$ may lead to a reduction in capillary permeability at low concentrations (at 5,10 , and 50 $\mu \mathrm{mol} \mathrm{L}{ }^{-1}$ ).

\section{Conclusions}

We have developed a facile and efficient method for the synthesis of benzothiazole amide derivatives via a nucleophilic acyl substitution reaction of 2-aminobenzothiazole with cinnamic acid compounds. Products bearing methoxy groups were easily obtained in high yields (up to 93\%) and had suitable thermal stabilities as demonstrated by thermogravimetric analysis. Compound Q2 showed good hemostatic activity, with a significantly shortened APTT and TT, reduced CNP level, activated thrombin activity, and more potent platelet aggregation activity compared to etamsylate (up to 1283.9 times), indicating that these benzothiazole amide derivatives, and particularly Q2, should be further screened for the possible generation of potential hemostatic drug molecules.

\section{Experimental}

\section{Materials and methods}

A series of cinnamic acid derivatives of analytical grade were purchased from Shengshun Trading Co., Ltd. (Zhuhai, China). 2-Aminobenzothiazole was purchased from Aladdin reagents (Shanghai, China). Etamsylate was purchased from Hubei Tianyao Pharmaceutical Co., Ltd. APTT, PT, and TT test kits were purchased from Heall Bio-Science Technology, Qingdao, China. ADP was purchased from Sigma-Aldrich (Shanghai, China). Human CNP ELISA Kit were purchased from Shanghai mlbio Biotechnology Co. (Shanghai, China). Thrombin ( $\geq 1000$ NIH U $\mathrm{mg}^{-1}$ protein) prepared from human plasma was purchased from Sigma-Aldrich (USA). Chromozym-TH was purchased from Roche (Swiss). All other reagents were commercial materials of analytical purity and were used without further purification.

${ }^{1} \mathrm{H}$ and ${ }^{13} \mathrm{C}$ NMR spectra were performed in dimethylsulfoxide- $d_{6}$ on a Bruker Ascend 600 at $600 \mathrm{MHz}$ for ${ }^{1} \mathrm{H}$ and 150 $\mathrm{MHz}$ for ${ }^{13} \mathrm{C}$, respectively. X-ray crystallographic studies were 
performed using a Nonius Kappa CCD diffractometer equipped with a graphite monochromator and an Oxford cryostream, using Mo-K $\alpha$ radiation $(\lambda=0.7107 \AA)$. Infrared spectra were performed as $\mathrm{KBr}$ sheets on a Tensor 27 FTIR spectrometer (Bruker, Germany). ESI-MS were collected using a LC-MS 2010A instrument (Shimadzu, Japan).

Plasma coagulation assays and platelet aggregation determination were performed using a blood coagulation analyzer (LG-PABER-I, GTM-STEELLEX Instrument Co., Ltd., Beijing, China). The enzyme-drug reaction was monitored using a BIORAD iMark microplate reader.

\section{Synthesis of compound Q1-Q4}

As shown in Scheme 1, cinnamic acid compounds (25.0 g; compound 1) and pyridine $(5 \mathrm{~mL})$ were added to a solution of acetic anhydride $(100 \mathrm{~mL})$. After the addition, the solution was stirred at $120{ }^{\circ} \mathrm{C}$ for $5 \mathrm{~h}$ using an oil bath. Deionized water $(800$ $\mathrm{mL}$ ) was added and the crude acetoxy intermediate (compound 2) was precipitated and separated. ${ }^{39}$ Compound 2 (1.5 mmol) was dissolved in $N, N$-dimethylformamide $(1 \mathrm{~mL})$ and thionyl chloride $(10 \mathrm{~mL})$, and stirred at $70{ }^{\circ} \mathrm{C}$ for $5 \mathrm{~min}$. Through distillation under reduced pressure, the liquid residue was collected and dispersed in $20 \mathrm{~mL}$ of $\mathrm{CH}_{2} \mathrm{Cl}_{2}$, to which 2-aminobenzothiazole $(1.0 \mathrm{mmol})$ was added, and stirred at $0-5{ }^{\circ} \mathrm{C}$. The $\mathrm{pH}$ value was kept between 6 and 7 by addition of $\mathrm{NaHCO}_{3}$ to induce precipitation. The upper layer solid was then collected by filtration of the mixture, and washed with excess distilled ethanol and water to obtain the pure products. Data for compounds Q1-Q4 are given below.

(E)-4-(3-(Benzo[ $d]$ thiazol-2-ylamino)-3-oxoprop-1-en-1-yl)2-methoxyphenyl acetate (Q1). White powder, yield $82 \%, \mathrm{mp}$ 183.0-184.9 ${ }^{\circ} \mathrm{C}$; IR (KBr) $\nu\left(\mathrm{cm}^{-1}\right): 1765,1633,1618,1198 ;{ }^{1} \mathrm{H}$ NMR (600 MHz, DMSO- $\left.d_{6}\right) \delta 12.57(\mathrm{~s}, 1 \mathrm{H}), 8.00(\mathrm{~d}, 1 \mathrm{H}, J=$ $7.70 \mathrm{~Hz}), 7.80(\mathrm{~d}, 1 \mathrm{H}, J=15.58 \mathrm{~Hz}), 7.77(\mathrm{~d}, 1 \mathrm{H}, J=8.00 \mathrm{~Hz})$, $7.44(\mathrm{~m}, 2 \mathrm{H}), 7.32(\mathrm{~m}, 1 \mathrm{H}), 7.28(\mathrm{dd}, 1 \mathrm{H}, J=1.76$ and 8.19 $\mathrm{Hz}), 7.20(\mathrm{~d}, 1 \mathrm{H}, J=8.12 \mathrm{~Hz}), 6.97(\mathrm{~d}, 1 \mathrm{H}, J=15.80 \mathrm{~Hz}), 3.85$ $(\mathrm{s}, 3 \mathrm{H}), 2.28(\mathrm{~s}, 3 \mathrm{H}) ;{ }^{13} \mathrm{C}$ NMR $\left(151 \mathrm{MHz}, \mathrm{DMSO}-d_{6}\right) \delta 168.37$, $164.00,158.02,151.17,148.68,142.47,140.96,133.20$, 131.69, 126.13, 123.57, 121.72, 120.57, 119.71, 112.35, 55.86, 20.39; ESI-MS $m / z 366.7(\mathrm{M}-\mathrm{H})^{-}$.

(E)-4-(3-(Benzo[d]thiazol-2-ylamino)-3-oxoprop-1-en-1-yl) phenyl acetate $(\mathbf{Q} 2)$. White powder, yield 73\%, mp 183.0$184.9{ }^{\circ} \mathrm{C}$; IR (KBr) $\nu\left(\mathrm{cm}^{-1}\right): 1756,1641,1596 ;{ }^{1} \mathrm{H}$ NMR $(600$ $\left.\mathrm{MHz}, \mathrm{DMSO}-d_{6}\right) \delta 12.64(\mathrm{~s}, 1 \mathrm{H}), 8.00(\mathrm{~d}, 1 \mathrm{H}, J=7.90 \mathrm{~Hz}), 7.81$ $(\mathrm{d}, 1 \mathrm{H}, J=15.80 \mathrm{~Hz}), 7.77(\mathrm{~d}, 1 \mathrm{H}, J=7.96 \mathrm{~Hz}), 7.71(\mathrm{~d}, 2 \mathrm{H}, J$ $=8.59 \mathrm{~Hz}), 7.45(\mathrm{t}, 1 \mathrm{H}, J=8.25 \mathrm{~Hz}), 7.32(\mathrm{t}, 1 \mathrm{H}, J=7.57 \mathrm{~Hz})$, $7.25(\mathrm{~d}, 2 \mathrm{H}, J=8.59 \mathrm{~Hz}), 6.94(\mathrm{~d}, 1 \mathrm{H}, J=15.82 \mathrm{~Hz}), 2.29(\mathrm{~s}$, $3 \mathrm{H}) ;{ }^{13} \mathrm{C}$ NMR $\left(151 \mathrm{MHz}, \mathrm{DMSO}-d_{6}\right) \delta 169.00,164.00,158.07$, $151.97,148.67,142.15,131.84,131.78,129.35,126.13$, $123.56,122.60,121.72,120.59,119.55,20.86$; ESI-MS $\mathrm{m} / \mathrm{z}$ $336.8(\mathrm{M}-\mathrm{H})^{-}$.

(E)-3-(3-(Benzo[d]thiazol-2-ylamino)-3-oxoprop-1-en-1-yl) phenyl acetate (Q3). White powder, yield 77\%, mp 197.2$197.8{ }^{\circ} \mathrm{C}$; IR (KBr) $\nu\left(\mathrm{cm}^{-1}\right): 1754,1694,1578 ;{ }^{1} \mathrm{H}$ NMR $(600$ $\left.\mathrm{MHz} \mathrm{CDCl}_{3}\right) \delta 12.76(\mathrm{~s}, 1 \mathrm{H}), 7.93(\mathrm{~d}, 1 \mathrm{H}, J=7.43 \mathrm{~Hz}), 7.87$ $(\mathrm{d}, 1 \mathrm{H}, J=15.58 \mathrm{~Hz}), 7.85(\mathrm{~d}, 1 \mathrm{H}, J=7.97 \mathrm{~Hz}) 7.44(\mathrm{t}, 1 \mathrm{H}, J=$
$8.18 \mathrm{~Hz}), 7.38(\mathrm{t}, 1 \mathrm{H}, J=7.55 \mathrm{~Hz}), 7.30(\mathrm{t}, 1 \mathrm{H}, J=7.86 \mathrm{~Hz})$, $7.19(\mathrm{~d}, 1 \mathrm{H}, J=7.75 \mathrm{~Hz}), 7.09(\mathrm{~d}, 1 \mathrm{H}, J=9.53 \mathrm{~Hz}), 7.03(\mathrm{t}, 1 \mathrm{H}$, $J=1.63 \mathrm{~Hz}), 6.67(\mathrm{~d}, 1 \mathrm{H}, J=15.59 \mathrm{~Hz}), 2.30(\mathrm{~s}, 3 \mathrm{H}) ;{ }^{13} \mathrm{C} \mathrm{NMR}$ $\left(151 \mathrm{MHz}, \mathrm{CDCl}_{3}\right) \delta 169.27,164.24,161.16,151.11,147.64$, $144.24,135.59,132.28,129.96,126.95,126.42,124.17$, $124.11,122.07,121.07,120.21,119.36,21.22$; ESI-MS $\mathrm{m} / \mathrm{z}$ $336.8(\mathrm{M}-\mathrm{H})^{-}$.

(E)-2-(3-(Benzo[ $d]$ thiazol-2-ylamino)-3-oxoprop-1-en-1-yl) phenyl acetate (Q4). White powder, yield 70\%, mp 197.2$197.8^{\circ} \mathrm{C}$; IR (KBr) $\nu\left(\mathrm{cm}^{-1}\right): 1762,1679,1602 ;{ }^{1} \mathrm{H}$ NMR $(600$ $\left.\mathrm{MHz}, \mathrm{CDCl}_{3}\right) \delta 12.61(\mathrm{~s}, 1 \mathrm{H}), 8.04(\mathrm{~d}, 1 \mathrm{H}, J=15.64 \mathrm{~Hz}), 7.95$ $(\mathrm{d}, 1 \mathrm{H}, J=7.33 \mathrm{~Hz}), 7.87(\mathrm{~d}, 1 \mathrm{H}, J=7.85 \mathrm{~Hz}), 7.42(\mathrm{~m}, 3 \mathrm{H})$, $7.30(\mathrm{t}, 1 \mathrm{H}, J=7.84 \mathrm{~Hz}), 7.13(\mathrm{~d}, 1 \mathrm{H}, J=8.09 \mathrm{~Hz}), 7.09(\mathrm{t}, 1 \mathrm{H}$, $J=7.58 \mathrm{~Hz}), 6.69(\mathrm{~d}, 1 \mathrm{H}, J=15.62 \mathrm{~Hz}), 2.37(\mathrm{~s}, 3 \mathrm{H}) ;{ }^{13} \mathrm{C} \mathrm{NMR}$ $\left(151 \mathrm{MHz}, \mathrm{CDCl}_{3}\right) \delta 169.38,164.14,160.87,149.77,147.76$, $138.35,132.28,131.69,127.40,126.86,126.71,126.28$, 124.33, 123.33, 122.06, 120.43, 120.11, 21.07; ESI-MS $\mathrm{m} / \mathrm{z}$ $336.8(\mathrm{M}-\mathrm{H})^{-}$.

\section{Synthesis of compound Q5-Q9}

Cinnamic acid compounds (1.5 mmol) and $\mathrm{N}, \mathrm{N}$-dimethylformamide $(1 \mathrm{~mL})$ were added to $10 \mathrm{~mL}$ of thionyl chloride, and allowed to react at $70{ }^{\circ} \mathrm{C}$ for $5 \mathrm{~min}$. The liquid residue obtained following distillation under reduced pressure was retained. A solution of the liquid residue in $\mathrm{CH}_{2} \mathrm{Cl}_{2}$ was added dropwise to a $\mathrm{CH}_{2} \mathrm{Cl}_{2}$ solution of 2-aminobenzothiazole (1.0 $\mathrm{mmol}$ ) under ice cooling. The mixture was stirred at $0-5{ }^{\circ} \mathrm{C}$ for 3 hours. TLC was used to monitor whether the reaction had completed. The $\mathrm{pH}$ value was kept between 6 and 7 by addition of $\mathrm{NaHCO}_{3}$ to induce precipitation. After the reaction, the amides were isolated using filtration of the mixture and then washed with excess distilled ethanol and water to obtain the pure products. The synthesis route is shown in Scheme 2 and the data for compounds Q5-Q9 are indicated below.

$\boldsymbol{N}$-(Benzo $[\boldsymbol{d}]$ thiazol-2-yl)cinnamamide (Q5). White powder, yield $88 \%, \mathrm{mp} 187.3-189.8{ }^{\circ} \mathrm{C}$; IR (KBr) $\nu\left(\mathrm{cm}^{-1}\right): 1698,1634$, $1601 ;{ }^{1} \mathrm{H}$ NMR (600 MHz, DMSO- $\left.d_{6}\right) \delta 12.60(\mathrm{~s}, 1 \mathrm{H}), 8.00(\mathrm{~d}, 1 \mathrm{H}, J$ $=7.74 \mathrm{~Hz}), 7.80(\mathrm{~d}, 1 \mathrm{H}, J=15.82 \mathrm{~Hz}), 7.77(\mathrm{~d}, 1 \mathrm{H}, J=8.01 \mathrm{~Hz})$, $7.67(\mathrm{~m}, 2 \mathrm{H}), 7.46(\mathrm{~m}, 4 \mathrm{H}), 7.32(\mathrm{~d}, 1 \mathrm{H}, J=7.52 \mathrm{~Hz}), 6.97(\mathrm{~d}, 1 \mathrm{H}, J$ $=15.82 \mathrm{~Hz}) ;{ }^{13} \mathrm{C}$ NMR $\left(151 \mathrm{MHz}, \mathrm{DMSO}-d_{6}\right) \delta 164.02,158.05$, 148.68, 143.11, 134.19, 131.69, 130.52, 129.11, 128.12, 126.13, 123.56, 121.72, 120.54, 119.40; ESI-MS $m / z 280.8(\mathrm{M}+\mathrm{H})^{+}$.

$(E)-N$-(Benzo[ $d]$ thiazol-2-yl)-3-(4-methoxyphenyl)acrylamide (Q6). White powder, yield 90\%, mp 201.8-202.3 ${ }^{\circ} \mathrm{C}$; IR (KBr) $\nu$ $\left(\mathrm{cm}^{-1}\right): 1681,1624,1162 ;{ }^{1} \mathrm{H}$ NMR $\left(600 \mathrm{MHz}, \mathrm{DMSO}-d_{6}\right) \delta 12.49$ $(\mathrm{s}, 1 \mathrm{H}), 7.98(\mathrm{~d}, 1 \mathrm{H}, J=7.80 \mathrm{~Hz}), 7.75(\mathrm{~m}, 2 \mathrm{H}), 7.52(\mathrm{~d}, 2 \mathrm{H}, J=$ $8.55 \mathrm{~Hz}), 7.44(\mathrm{t}, 1 \mathrm{H}, J=7.55 \mathrm{~Hz}), 7.30(\mathrm{t}, 1 \mathrm{H}, J=7.47 \mathrm{~Hz}), 7.03$ $(\mathrm{d}, 2 \mathrm{H}, J=8.55 \mathrm{~Hz}), 6.82(\mathrm{~d}, 1 \mathrm{H}, J=15.75 \mathrm{~Hz}), 3.81(\mathrm{~s}, 3 \mathrm{H}) ;{ }^{13} \mathrm{C}$ NMR (151 MHz, DMSO- $\left.d_{6}\right) \delta 164.36,161.19,158.27,148.72$, $142.87,131.70,129.90,126.80,126.06,123.43$, 121.66, 120.43, 116.78, 114.58, 55.36; ESI-MS $m / z$ 309.2 (M - H $)^{-}$.

(E)- $N$-(Benzo[d]thiazol-2-yl)-3-(3,4-dimethoxyphenyl)acrylamide (Q7). White powder, yield 92\%, mp 204.4-206.8 ${ }^{\circ} \mathrm{C}$; IR (KBr) $\nu$ $\left(\mathrm{cm}^{-1}\right): 1701,1639,1159 ;{ }^{1} \mathrm{H}$ NMR (600 MHz, DMSO- $\left.d_{6}\right), \delta 12.44(\mathrm{~s}$, $1 \mathrm{H}), 7.99(\mathrm{~d}, 1 \mathrm{H}, J=7.69 \mathrm{~Hz}), 7.75(\mathrm{t}, 2 \mathrm{H}, J=11.59 \mathrm{~Hz}), 7.44(\mathrm{~d}, 1 \mathrm{H}$, $J=7.65 \mathrm{~Hz}), 7.31(\mathrm{~d}, 1 \mathrm{H}, J=7.54 \mathrm{~Hz}), 7.25(\mathrm{~m}, 2 \mathrm{H}), 7.05(\mathrm{~d}, 1 \mathrm{H}, J=$ 
$8.83 \mathrm{~Hz}), 6.85(\mathrm{~d}, 1 \mathrm{H}, J=15.73 \mathrm{~Hz}), 3.83(\mathrm{~s}, 3 \mathrm{H}), 3.81(\mathrm{~s}, 3 \mathrm{H}) ;{ }^{13} \mathrm{C}$ NMR (151 MHz, DMSO- $\left.d_{6}\right) \delta 164.36,158.17,151.06,148.96,148.69$, 143.26, 131.70, 127.02, 126.10, 123.48, 122.31, 121.68, 120.47, 116.98, 111.84, 110.62, 55.68, 55.50; ESI-MS m/z $340.9(\mathrm{M}+\mathrm{H})^{+}$.

(E)-N-(Benzo[d]thiazol-2-yl)-3-(3,4,5-trimethoxyphenyl)acrylamide (Q8). Yellow powder, yield 93\%, mp 137.4-138.8 ${ }^{\circ} \mathrm{C}$; IR ( $\left.\mathrm{KBr}\right) \nu$ $\left(\mathrm{cm}^{-1}\right): 1703,1633,1153 ;{ }^{1} \mathrm{H}$ NMR $\left(600 \mathrm{MHz}, \mathrm{CDCl}_{3}\right) \delta 12.95(\mathrm{~s}, 1 \mathrm{H})$, $7.91(\mathrm{~d}, 1 \mathrm{H}, J=7.83 \mathrm{~Hz}), 7.85(\mathrm{dd}, 2 \mathrm{H}, J=11.88$ and $14.24 \mathrm{~Hz}), 7.42$ $(\mathrm{t}, 1 \mathrm{H}, J=7.35 \mathrm{~Hz}), 7.35(\mathrm{t}, 1 \mathrm{H}, J=7.53 \mathrm{~Hz}), 6.60(\mathrm{~m}, 3 \mathrm{H}), 3.87(\mathrm{~s}$, $3 \mathrm{H}), 3.65$ (s, 6H); ${ }^{13} \mathrm{C}$ NMR (151 MHz, $\left.\mathrm{CDCl}_{3}\right) \delta 164.58,161.28$, $153.55,147.58,145.55,140.73,132.23,129.47,126.93,124.23$, $122.05,120.10,117.45,105.72,61.12,56.16$; ESI-MS $m / z 368.8(\mathrm{M}-$ $\mathrm{H})^{-}$.

$\boldsymbol{N}$-(Benzo[d]thiazol-2-yl)-3-phenylpropanamide (Q9). White powder, yield 90\%, mp 197.3-199.9 ${ }^{\circ} \mathrm{C}$; IR $(\mathrm{KBr}) \nu\left(\mathrm{cm}^{-1}\right): 1756$, 1641, 1596; ${ }^{1} \mathrm{H}$ NMR (600 MHz, DMSO- $d_{6}$ ) $\delta 12.36$ (s, 1H), 7.96 $(\mathrm{d}, 1 \mathrm{H}, J=7.58 \mathrm{~Hz}), 7.72(\mathrm{~d}, 1 \mathrm{H}, J=8.01 \mathrm{~Hz}), 7.42(\mathrm{t}, 1 \mathrm{H}, J=7.66$ $\mathrm{Hz}), 7.28(\mathrm{~m}, 5 \mathrm{H}), 7.18(\mathrm{t}, 1 \mathrm{H}, J=7.11 \mathrm{~Hz}), 2.95(\mathrm{t}, 2 \mathrm{H}, J=7.72$ $\mathrm{Hz}), 2.82(\mathrm{t}, 2 \mathrm{H}, J=7.74 \mathrm{~Hz}) ;{ }^{13} \mathrm{C}$ NMR $\left(151 \mathrm{MHz}, \mathrm{DMSO}-d_{6}\right)$ $\delta 171.46,157.82,148.52,140.65,131.42,128.36,128.26,126.08$, 126.05, 123.45, 121.65, 120.46, 36.81, 30.24; ESI-MS $\mathrm{m} / \mathrm{z} 280.8$ $(\mathrm{M}-\mathrm{H})^{-}$.

\section{Crystallographic data collection and structure determination}

Single-crystal X-ray diffraction data of compounds Q7 and Q9 was collected on a CCD area detector diffractometer with graphite monochromated $\mathrm{Mo} / \mathrm{K} \alpha$ radiation $(\lambda=0.071073 \mathrm{~nm})$. The structures were solved by direct methods using Olex2 software $^{\mathbf{4 0}}$ and refined with full-matrix least squares on $F^{2}$ using the ShelXL ${ }^{41}$ program package. All non-hydrogen atoms were refined anisotropically. The hydrogen atoms attached to all carbon and nitrogen atoms were geometrically fixed and the positional and temperature factors were refined isotropically. Structural illustrations were generated using Diamond 3.1 for Windows.

\section{Thermogravimetric analysis}

The thermogravimetric experiments were performed using a NETZSCH STA 409 PC/PG thermogravimetric analyzer under air atmosphere at a flow rate of $20 \mathrm{~mL} \mathrm{~min}^{-1}$ for the sample. The explored temperature interval ranged between $30{ }^{\circ} \mathrm{C}$ and $250{ }^{\circ} \mathrm{C}$, at a heating rate of $0.5{ }^{\circ} \mathrm{C} \mathrm{min}^{-1}$. The decomposition temperature $\left(T_{\mathrm{d}}\right)$ was taken at the maximum of the heat flow peaks $^{42}$ and the maximum heat flux changes occurred at the same point.

\section{Human plasma samples}

Healthy volunteers (aged 20-25) were recruited for this study. Whole blood was drawn from the volunteer's hand vein. The fresh vein blood samples were collected in the morning with overnight fasting using routine procedures. Blood was collected in plastic tubes with $3.8 \%$ sodium citrate (citrate/blood: $1 / 9, \mathrm{v} / \mathrm{v}$ ) to ensure plasma anticoagulation. ${ }^{43}$ Samples were centrifuged for 15 minutes at $1000 \times g$ at $2-8{ }^{\circ} \mathrm{C}$ within 30 minutes of collection.
Live subject statement. All experiments concerning healthy human plasma were performed in compliance with accordance with the WHO guidelines on blood drawing (WHO Publication ISBN-13: 978-92-4-159922-1, 2010), and approved by the ethics committee at the Ethics Committee of First Affiliated Hospital of Guangxi Medical University. All experiments concerning human volunteers were performed after obtaining informed consent.

\section{Platelet aggregation determination in vitro}

Functional promotion activity of the nine synthesized compounds was evaluated by measuring the promotion of ADPinduced platelet aggregation in human platelet-rich plasma (PRP) by Born's method. ${ }^{44}$ PRP was prepared from collected blood by low speed centrifugation at $800 \mathrm{rpm}$ for $10 \mathrm{~min}$ at $24{ }^{\circ} \mathrm{C}$, whereas platelet-poor plasma (PPP) was prepared by centrifuging PRP at $3000 \mathrm{rpm}$ for a further $10 \mathrm{~min}$. ADP was selected as an agonist for platelet aggregation test.

Light transmission of $100 \%$ was calibrated by $280 \mu \mathrm{L}$ PPP and $20 \mu \mathrm{L}$ sample solution (samples were dissolved and diluted with $80 \%$ macrogol 400 ), and then platelet aggregation was induced by the addition of ADP (final concentration: $5 \mu \mathrm{mol}$ $\mathrm{L}^{-1}$ ) to $280 \mu \mathrm{L}$ PRP and $20 \mu \mathrm{L}$ sample solution. Platelet aggregation kinetics were measured and platelet aggregation was expressed as a percentage of the PPP transmission value. The changes in light transmission were recorded. Experiments were completed within $3 \mathrm{~h}$ after blood collection.

\section{Blood coagulation assay in vitro}

The activation of APTT, PT, and TT assays were examined by commercial kits following the manufacturer's instructions using a hematology analyzer. Samples were dissolved in and diluted with $80 \%$ macrogol 400 . A $100 \mu \mathrm{L}$ aliquot of the sample solution was then mixed with $900 \mu \mathrm{L}$ of plasma and incubated at $37^{\circ} \mathrm{C}$ for $5 \mathrm{~min}$. APTT was determined by incubating $50 \mu \mathrm{L}$ of the plasma solution with $50 \mu \mathrm{L}$ of APTT activating agent for $3 \mathrm{~min}$ at $37^{\circ} \mathrm{C}$, followed by addition of $50 \mu \mathrm{L}$ of $\mathrm{CaCl}_{2}(25 \mathrm{mM})$. PT was determined by incubating $50 \mu \mathrm{L}$ of the plasma solution for $3 \mathrm{~min}$ at $37^{\circ} \mathrm{C}$, followed by addition of $100 \mu \mathrm{L}$ of thromboplastic agent. TT was determined by incubating $50 \mu \mathrm{L}$ of the plasma solution for $3 \mathrm{~min}$ at $37^{\circ} \mathrm{C}$, followed by addition of 100 $\mu \mathrm{L}$ of APTT activating agent.

The coagulation activity was assessed by assaying the plasma clotting time of TT and APTT, and the decrease in International Normalized Ratio (INR) of PT.

The $R_{\mathrm{APTT}}, R_{\mathrm{PT}}$, or $R_{\mathrm{TT}}$ were calculated as follows:

$$
\begin{gathered}
R_{\mathrm{APTT}}=\frac{\mathrm{APTT}_{C}-\mathrm{APTT}_{0}}{\mathrm{APTT}_{0}} \times 100 \% \\
R_{\mathrm{PT}}=\frac{\mathrm{PT}_{C}-\mathrm{PT}_{0}}{\mathrm{PT}_{0}} \times 100 \% \\
R_{\mathrm{TT}}=\frac{\mathrm{TT}_{C}-\mathrm{TT}_{0}}{\mathrm{TT}_{0}} \times 100 \%
\end{gathered}
$$


In this set of equations, $\mathrm{APTT}_{C}, \mathrm{PT}_{C}$, and $\mathrm{TT}_{C}$ correspond to the APTT, PT, and TT at determined sample concentrations. The factors $\mathrm{APTT}_{0}, \mathrm{PT}_{0}$, and $\mathrm{TT}_{0}$ correspond to the control assays in which the concentration of the sample was $0 \mu \mathrm{M}$. All the data were obtained as mean $(n=8)$ values.

\section{Determination of thrombin activity}

The thrombin activation assay was conducted using the chromogenic substrate method. The substrate Tos-Gly-ProArg-pNA (chromozym-TH) can be hydrolyzed by thrombin and cleaved into two parts, a residual peptide and a yellow substance, $p$-nitroaniline, which can be measured with a microplate reader. A $20 \mu \mathrm{L}$ aliquot of the thrombin solution ( $1 \mathrm{U} \mathrm{mL}^{-1}$, in $0.1 \%$ bovine serum albumin, $\mathrm{pH} 6.5$ ) was mixed with $20 \mu \mathrm{L}$ of the test compound solution (dissolved in $50 \mathrm{mM}$ Tris buffer, $\mathrm{pH}$ 8.3). The mixture was incubated at $37^{\circ} \mathrm{C}$ for $10 \mathrm{~min}$ before the addition of $20 \mu \mathrm{L}$ of chromozym-TH solution $(2 \mathrm{mM})$. After a further $10 \mathrm{~min}$ of incubation at $37^{\circ} \mathrm{C}, 50 \mu \mathrm{L}$ of acetic acid $(50 \% \mathrm{w} / \mathrm{v})$ and $40 \mu \mathrm{L}$ of water were successively added to terminate the reaction. For each concentration, three replicate wells were used. The absorbance was monitored at $405 \mathrm{~nm}$. The Tris-treated control was considered the blank control. The $\mathrm{EC}_{50}$ values represent the concentration that caused a $50 \%$ activation relative to the Tris-treated control.

\section{Molecular docking}

A molecular docking study was performed to investigate the binding mode between Q2 and human thrombin using Autodock vina 1.1.2. ${ }^{31}$ The three-dimensional (3D) structure of human thrombin (PDB ID: 3RLW) was downloaded from Protein Data Bank (http://www.rcsb.org/pdb/home/home.do). The 3D structure of Q2 was drawn by ChemBioDraw Ultra 14.0 and ChemBio3D Ultra 14.0 software. The AutoDockTools 1.5.6 package ${ }^{45,46}$ was employed to generate the docking input files. The search grid of the thrombin was identified as center $x$ : 16.154, center_y: -14.375 , and center_z: 23.051 with dimensions size_x: 15, size_y: 15, and size_z: 15 . The value of exhaustiveness was set to 20. For Vina docking, the default parameters were used unless specifically mentioned. The bestscoring pose as judged by the Vina docking score was chosen and visually analyzed using PyMoL 1.7.6 software (http://www.pymol.org/).

\section{Human CNP determination}

Samples were dissolved in and diluted with $80 \%$ polyethylene glycol 400. A $20 \mu \mathrm{L}$ aliquot of the sample solution was then mixed with $80 \mu \mathrm{L}$ of plasma and incubated at $37^{\circ} \mathrm{C}$ for $15 \mathrm{~min}$. The plasma mixed solution was assayed with a Human CNP ELISA kit according to the manufacturer's instructions. The enzymatic activity was examined at $450 \mathrm{~nm}$ using a microplate reader. All samples were assayed in triplicate. Finally, the contents were calculated according to the standard curves.

\section{Statistical analysis}

Significant differences between the groups were determined using a one-way analysis of variance (ANOVA) in SPSS 22.0 (SPSS Inc., Chicago, Illinois, USA), followed by Dunnett's test with $P<0.05$. The $\mathrm{EC}_{50}$ values were determined using linear regression in SPSS 22.0.

\section{Conflicts of interest}

There are no conflicts to declare.

\section{Acknowledgements}

This work was financially supported by the National Natural Science Foundation of China (21362001), and the Guangxi Key Laboratory of Traditional Chinese Medicine Quality Standards (guizhongzhongkai201104). We acknowledge MogoEdit (a professional English editing company) for English revision of the manuscript.

\section{References}

1 W. C. Wu, A. Trivedi, P. D. Friedmann, W. G. Henderson, T. S. Smith, R. M. Poses, G. Uttley, M. Vezeridis, C. B. Eaton and V. Mor, Ann. Surg., 2012, 255, 708.

2 E. Schindler, J. Photiadis, N. Sinzobahamvya, A. Döres, B. Asfour and V. Hraska, Eur. J. Cardiothorac. Surg., 2011, 39, 495-499.

3 Can Drugs Reduce Surgical Blood Loss?, The Lancet, 331(8578), 155-156.

4 B. L. Erstad, Ann. Pharmacother., 2001, 35, 925.

5 M. Verstraete, Drugs, 1985, 29, 236-261.

6 D. T. Mangano, I. C. Tudor and C. Dietzel, N. Engl. J. Med., 2006, 354, 353.

7 S. Durgamma, P. R. Reddy, V. Padmavathi and A. Padmaja, J. Heterocycl. Chem., 2015, 53, 738-747.

8 N. B. Patel and F. M. Shaikh, Sci. Pharm., 2010, 78, 753-765.

9 D. L. N. Surleraux, P. T. B. P. Wigerinck and D. P. Getman, WO 2004/014371 Al, 2010.

10 C. R. Gardner, B. B. Cheung, J. Koach, D. S. Black, G. M. Marshall and N. Kumar, Bioorg. Med. Chem., 2012, 20, 6877-6884.

11 P. K. Deb, R. Kaur, B. Chandrasekaran, M. Bala, D. Gill, V. R. Kaki, R. R. Akkinepalli and R. Mailavaram, Med. Chem. Res., 2014, 23, 2780-2792.

12 K. Yamazaki, Y. Kaneko, K. Suwa, S. Ebara, K. Nakazawa and K. Yasuno, Bioorg. Med. Chem., 2005, 13, 2509-2522.

13 O. R. Thiel, C. Bernard, T. King, M. Dilmeghaniseran, T. Bostick, R. D. Larsen and M. M. Faul, J. Org. Chem., 2008, 73, 3508-3515.

14 D. J. Newman and G. M. Cragg, J. Nat. Prod., 2012, 75, 311335.

15 B. Aneja, B. Kumar, M. A. Jairajpuri and M. Abid, ChemInform, 2016, 47, 18364-18406.

16 W. Nong, A. Zhao, J. Wei, X. Lin, L. Wang and C. Lin, Bioorg. Med. Chem. Lett., 2017, 4506-4511. 
17 C. W. Lin, F. Y. Meng, F. Q. Lin, J. R. Wei and C. R. Du, China Pat., CN103288752A, 2013.

18 S. Durgamma, A. Muralikrishna, V. Padmavathi and A. Padmaja, Med. Chem. Res., 2014, 23, 2916-2929.

19 R. F. Pellon and M. L. Docampo, Synth. Commun., 2013, 43, 537-552.

20 H. Youn, L. Hyun-Joo, K. Eun-Kyung, P. Jin-Hwi and J. JaeEun, WO2013043002A1, 2013.

21 C. A. G. N. Montalbetti and V. Falque, Tetrahedron, 2006, 37, 10827-10852.

22 R. J. Watson, D. Batty, A. D. Baxter, D. R. Hannah, D. A. Owen and J. G. Montana, Tetrahedron Lett., 2002, 43, 683-685.

23 A. D. Michelson, The Platelets, Academic Press, 2002.

24 P. Harrison, Blood Rev., 2005, 19, 111-123.

25 M. L. Rand, R. Leung and M. A. Packham, Transfus. Apher. Sci., 2003, 28, 307.

26 L. Lv, F. Tang and G. Lan, RSC Adv., 2016, 6, 95358-95368.

27 L. Liu, J. A. Duan, Y. Tang, J. Guo, N. Yang, H. Ma and X. Shi, J. Ethnopharmacol., 2012, 139, 381.

28 W. E. Dager, R. C. Gosselin, S. Kitchen and D. Dwyre, Ann. Pharmacother., 2012, 46, 1627-1636.

29 N. Ayres, D. J. Holt, C. F. Jones, L. E. Corum and D. W. Grainger, J. Polym. Sci., Part A: Polym. Chem., 2008, 46, 7713-7724.

30 C. Pallister and M. Watson, Haematology, Scion Publishing Ltd.: Banbury UK, 2nd edn, 2010.

31 O. Trott and A. J. Olson, J. Comput. Chem., 2010, 31, 455-461. 32 N. Hama, H. Itoh, G. Shirakami, S. Suga, Y. Komatsu, T. Yoshimasa, I. Tanaka, K. Mori and K. Nakao, Biochem. Bioph. Res. Co., 1994, 198, 1177-1182.
33 I. Pham, S. Sediame, G. Maistre, F. Roudotthoraval, P. E. Chabrier, A. Carayon and S. Adnot, Am. J. Physiol., 1997, 273, 1457-1464.

34 M. Furuya, K. Aisaka, T. Miyazaki, N. Honbou, K. Kawashima, T. Ohno, S. Tanaka, N. Minamino, K. Kangawa and H. Matsuo, Biochem. Bioph. Res. Co., 1995, 748, 517.

35 A. Borchers, Hemostatic Drugs, Small Animal Critical Care Medicine, 2nd edn, 2015, ch. 170, pp. 893-898.

36 Q. Sun, Y. U. Hong-Qi and X. Z. Zhao, Chinese \& Foreign Medical Research, 2012, 32, 1-2.

37 A. Z. Liu and H. E. Zhe-Sheng, J. Fourth Mil. Med. Univ., 1993, 14, 221-222.

38 A. Z. Liu and Z. L. Zhang, Chin. J. Phys. Med. Rehabil., 2002, 23, 32-34.

39 J. Petersen, K. Hedberg and B. Christensen, Ind. Eng. Chem., Anal. Ed., 1943, 15, 225-226.

40 O. V. Dolomanov, L. J. Bourhis, R. J. Gildea, J. A. K. Howard and H. Puschmann, J. Appl. Crystallogr., 2009, 42, 339-341.

41 G. M. Sheldrick, Acta Crystallogr., 2015, 71, 3.

42 D. I. Donato, G. Lazzara and S. Milioto, J. Therm. Anal. Calorim., 2010, 101, 1085-1091.

43 M. Hussain, RSC Adv., 2015, 5, 54963-54970.

44 G. V. Born, Nature, 1962, 194, 927.

45 M. F. Sanner, J. Mol. Graphics Modell., 1999, 17, 57-61.

46 G. M. Morris, R. Huey, W. Lindstrom, M. F. Sanner, R. K. Belew, D. S. Goodsell and A. J. Olson, J. Comput. Chem., 2009, 30, 2785-2791. 